\title{
Generation and applications of human pluripotent stem cells induced into neural lineages and neural tissues
}

\section{Y. Martinez *, M. Dubois-Dauphin and K.-H. Krause}

Department of Pathology and Immunology, Faculty of Medicine, University of Geneva, Geneva, Switzerland

Edited by:

Anis Feki, Geneva University

Hospitals, Switzerland

\section{Reviewed by:}

Mohammad K. Hajihosseini,

University of East Anglia, UK

Petros Papagerakis, University of

Michigan, USA

${ }^{*}$ Correspondence:

Y. Martinez, Department of Pathology and Immunology, University of

Geneva, Faculty of Medicine, 1 Rue

Michel-Servet, 1206 Geneva,

Switzerland.

e-mail:yannick.martinez@unige.ch
Human pluripotent stem cells (hPSCs) represent a new and exciting field in modern medicine, now the focus of many researchers and media outlets. The hype is well-earned because of the potential of stem cells to contribute to disease modeling, drug screening, and even therapeutic approaches. In this review, we focus first on neural differentiation of these cells. In a second part we compare the various cell types available and their advantages for in vitro modeling. Then we provide a "state-of-the-art" report about two major biomedical applications: (1) the drug and toxicity screening and (2) the neural tissue replacement. Finally, we made an overview about current biomedical research using differentiated hPSCs.

Keywords: embryonic stem cell, induced pluripotent stem cells, engineered neural tissue, neurons, neural differentiation, cell transplantation, drug screening, cell therapy

\section{INTRODUCTION}

Human pluripotent stem cells (hPSCs) encompass human embryonic stem cells (hESC) and human induced pluripotent stem cells (hIPS); they are recently added tools in world of biological research. The first in vitro culture of hESC was established in 1998 and, even then, there was obvious interest in developmental biology, drug discovery, and transplantation medicine (Thomson et al., 1998). hIPS are cells in an embryonic stem cell-like state generated from non-pluripotent cells by induction of specific genes (Yu et al., 2007). hPSCs are functionally defined by their self-renewal and differentiation potential. They can be induced to differentiate in vitro into virtually all human cell types (Bhattacharya et al., 2009). A diseased or injured central nervous system (CNS) has little capacity to compensate for the loss of cellular elements (neurons, oligodendrocytes; Barrett et al., 2007), thus, cell replacement is an interesting prospective [i.e., missing dopaminergic neurons in Parkinson's diseased brain; missing motoneurons in amyotrophic lateral sclerosis (ALS) or spinal cord injury]. Significant progress has been made in culture and differentiation protocols to obtain cells suitable for transplantation. Further development of these technologies could lead to the scalable production of different neural cell types for toxicity screening and clinical therapies (Dantuma et al., 2010). Currently, 10 years after the first in vitro culture of hESC, the first therapy using hESC is being evaluated in clinical trials, beginning to make part of these promises a reality (Geron Corporation, 2009). However, in spite of numerous statements in the social media declaring that these cells can be used in medicine for therapeutic purposes, the clinical applications remain few (Aznar and Sanchez, 2011). hPSCs-derived neurons (-dN) are still too rarely used for drug screening and predictive toxicity. In these domains, requirements exist for efficient, predictive, and cost-effective in vitro models (Bal-Price et al., 2010). Such models have been established with hPSCs-dN but most in vitro models use mouse ESCs-dN. For each of these research domains, we will describe recent advances in hPSCs culture and we will focus on the clinical relevance of using hPSCs for in vitro nervous system disease modeling and therapies.

\section{hESC AND iPSCs DIFFERENTIATION TOWARD NEURAL LINEAGE \\ CELL LINES}

One major challenge in biomedical research is to recapitulate in vitro the biological events occurring in vivo in normal or diseased organs. There remain serious concerns with the relevance of the most commonly used model systems. For instance, human brain tissue obtained from postmortem samples is subject to numerous artifacts: abnormal brain $\mathrm{pH}$ resulting from near death hypoxia, a lengthy postmortem period, residual amounts of medications used. Although they are a major source for primary human neuron cultures, biopsies from the CNS are restricted, owing to the invasiveness of the procedure (Deep-Soboslay et al., 2011). Thus hESC-dN are an attractive alternative to primary neuron culture.

Human embryonic stem cells are derived from the inner cell mass of the 4- to 5-day-old blastocyst. These cells possess two hallmark characteristics: (1) they are able to proliferate in vitro and (2) under controlled culture conditions they are able to differentiate into all three germ layers (ectoderm, mesoderm, endoderm), and thereby represent a potentially inexhaustible source of somatic cells (Thomson et al., 1998). Growing knowledge about differentiation protocols allows the generation of cells found in neural tissue such as neurons and glia. However, the isolation of hESC raises ethical issues due to the destruction of human embryo. The development of hIPS avoids this ethical problem and is a good alternative to hESC.

There are several approaches to generate hIPS from adult somatic cells from various tissues, including nuclear transfer, cell fusion, and direct reprogramming (Hochedlinger and Jaenisch, 2006). The direct reprogramming of differentiated cells (i.e., 
fibroblasts) into hIPS provides a tractable source of pluripotent cells for regenerative therapy (Figure 1). Direct reprogramming was first realized by the transduction of four transcription factors in fibroblasts (Oct-3/4, Sox2, KLF4, and c-Myc - OSKM factors, Takahashi et al., 2007; Yamanaka, 2008). Cell reprogramming is usually achieved by methods involving viral-derived vectors, but there has been progress toward optimizing security. Several alternatives exist to replace some or all of the OSKM factors: pharmacological molecules, recombinant proteins, signaling factors or use of other transcription factors (Huangfu et al., 2008; Yoshida et al., 2009; Zhou et al., 2009; Gonzalez et al., 2011). More recently, the reprogramming of human somatic cells was driven by the expression of specific miRNA (Anokye-Danso et al., 2011). For therapeutic purposes, hIPS transgene-free were designed and some "safe" non-teratoma-forming cell lines have been identified (Okita et al., 2011). Although still subject to much controversy, hIPS proliferative and differentiation properties resemble hESC (Ohi et al., 2011). Both hESC and hIPS exhibit high intrinsic variability between different cell lines (Bock et al., 2011). Thus, the suitability of each cell line for clinical applications needs to be examined.

For disease modeling purposes, hIPS lines have been generated, for example, from patients affected by spinal muscular atrophy (SMA), familial dysautonomia (FD), Rett syndrome, and down syndrome (Baek et al., 2009; Hotta et al., 2009). Motor neurons derived from SMA or FD patients hIPS exhibited, in vitro, morphological features of the disease (Ebert et al., 2009; Lee et al.,

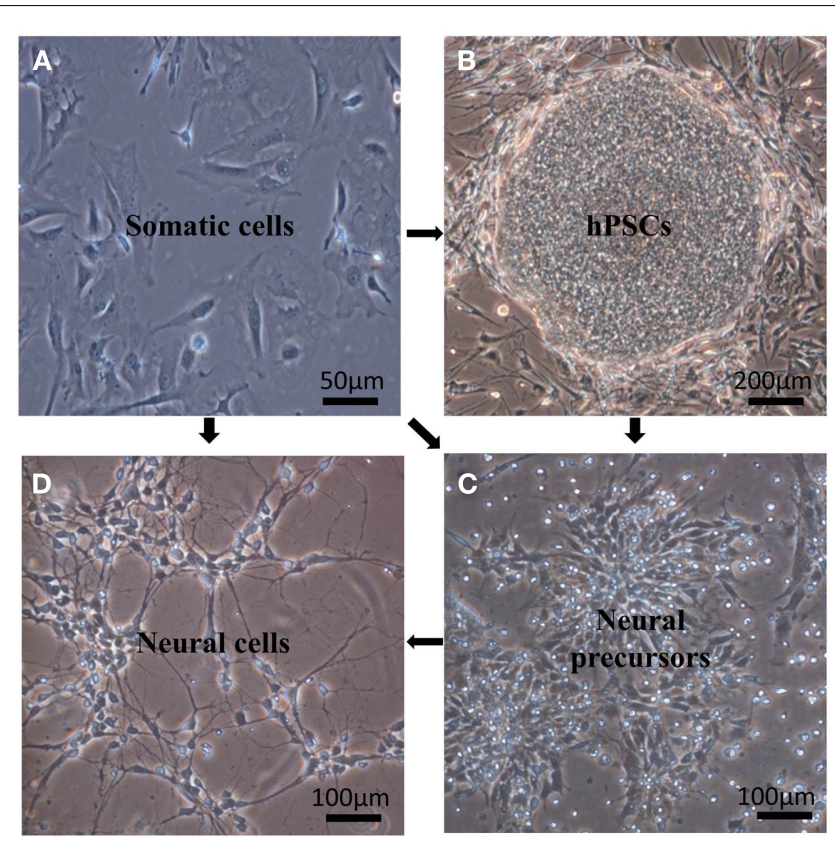

FIGURE 1 | Generation of neural precursors or neural cells from pluripotent stem cells using differentiation or somatic cells using transdifferentiation. (A) Fibroblasts used for direct reprogramming using the four transcription factors: Oct4, Sox2, KLF4, c-Myc. (B) hESC, H1 cell line cultured on mouse embryonic fibroblasts as feeder cells (MEFs). (C) Neural precursor cells obtained from differentiated H1. (D) Monolayer of neurons differentiated from $\mathrm{H} 1$.
2009). Since hIPS retain a "memory" and potential characteristics of the cells or related tissue they originate from (Tian et al., 2011), it was speculated that this memory could be helpful for modeling of late-onset neurological diseases such as ALS or Parkinson's disease (PD). Unfortunately, neurons derived from hIPS generated from ALS or PD patients do not readily recapitulate the diseases features (Dimos et al., 2008; Park et al., 2008; Soldner et al., 2009). The reprogramming of an adult cell to a pluripotent state may reset certain epigenetic hallmarks that developed during disease evolution. To avoid this problem, direct transdifferentiation of somatic cells to neural lineages could be considered. It is now possible to use direct reprogramming with human fibroblasts (with specific factors such as Ascl1, Brn2, Myt1l) to generate functional neurons (Vierbuchen et al., 2010; Kim et al., 2011; Pang et al., 2011) and more specifically, dopaminergic neurons (Pfisterer et al., 2011; Figure 1). However, these methods are inconvenient because they generate few cells; in the most recent protocols, about $20 \%$ of cells can be directly reprogrammed to functional neurons.

\section{DIFFERENTIATION}

Withdrawing a key factor from the medium or forcing the hPSCs to grow in suspension is enough to induce cell differentiation (Thomson et al., 1998). However, the stochastic nature of differentiating hPSCs generates many different somatic cell types (Martinez et al., 2011). hPSCs-based applications, mainly in the biomedical domain, require specific in vitro differentiation toward the desirable cell population harboring a unique phenotype. Cell preparations containing undifferentiated or insufficiently differentiated hPSCs can lead to cell overgrowth or teratoma formation once transplanted in an organism (Lees et al., 2007; Aubry et al., 2008). For a given neurodegenerative disorder, hPSCs must be differentiated toward the specific neural cell type that could potentially restore the lost functions (Table 2 ). For example cell replacement therapy to treat PD aims dopaminergic neurons (Marchetto et al., 2010).

The crucial point is how to induce specific hPSCs differentiation toward the desired neural phenotypes. The first step is to obtain neural progenitor cells (NPCs; Figure 1). Essentially, specific differentiation depends on the addition of instructive factors and the removal, or inhibition, of preventive ones (Nat and Hovatta, 2004). To obtain NPCs, many different factors have been tested (Reubinoff et al., 2001; Dhara and Stice, 2008; Suter et al., 2009). The most commonly used are fibroblast growth factor (FGF), EGF, SHH, retinoic acid (RA), and bone morphogenetic protein-antagonists $(\mathrm{BMPa})$; there is also the less well-defined stromal-cells derived inducing activity (SDIA). These factors are known to activate complex pathways such as Hedgehog, mesodermal, BMP, kinase, and WNT signaling but their roles are not entirely elucidated. To inhibit the differentiation toward lineages other than neural and promote neural differentiation, in most protocols, media supplements, such as N2 and B27, are added. N2 contain insulin, transferrin, putrescine, progesterone, and selenium. Insulin promotes proliferation, transferrin promotes proliferation and survival of mature neurons, putrescine is involved in axonal regeneration, and selenium protects against excitotoxicity. B27 contains more than 20 components including vitamins, hormone growth factors, antioxidants, and fatty acids (Suter and Krause, 
Table 1 | Main factors used for differentiation toward specific neural lineages.

\begin{tabular}{ll}
\hline Cell type & Factors needed for differentiation \\
\hline Neural precursor & $\beta F G F$, EGF \\
Dopamine neurons & FGF-8, Shh \\
GABA neurons & BDNF, Dkk1, Shh, cAMP \\
Motor neurons & RA, Shh \\
Astrocytes & CNTF, LIF, BMPs \\
Oligodendrocytes & PMN, VN, NGN, PDGF, cAMP, FGF-2 \\
Retinal neural cells & Dkk1, Lefty-1 \\
Auditory neural cells & $\beta F G F$, EGF, insulin-like growth factor, BMP4
\end{tabular}

$B D N F$, brain-derived neurotrophic factor; BMP4, bone morphogenetic factor 4; CAMP, cyclic adenosine monophosphate; CNTF, ciliary neurotrophic factor; Dkk1, Dickkopf-1; EGF, epidermal growth factor; FGF-8, fibroblast growth factor 8; GABA, g-aminobutyric acid; LIF, leukemia inhibitory factor; NGN, neurogenin; PDGF, platelet-derived growth factor; PMN, purmorphamine; $R A$, retinoic acid; Shh, Sonic hedgehog; VN, vitronectin (Suter and Krause, 2008).

2008). Ectodermal factors are also used to restrict mesoderm differentiation using P53 pathway (Sasai et al., 2008). Despite the numerous components tested and added, the effective maintenance and stable expansion of NPCs remains complicated, even with the most recently developed protocols (Li et al., 2011). Moreover, no protocol allows obtaining only NPCs; and a selection of cells of interest must be done with techniques like FACS sorting or with inducible suicide gene (Li, 2002; Kawaguchi et al., 2008).

The second step is to drive NPCs toward a specific neural phenotype (Figure 1). Many molecular pathways are involved in this step of differentiation. For example, Wnt/beta-catenin signaling is known to stimulate the formation of dopaminergic neurons (Ding et al., 2011). To get mature neural cell types, the presence of specific factors is necessary (Table 1). Yet, as for NPCs, the purity of neural cell population remains problematic (Pankratz et al., 2007). An additional consideration is that techniques for neural induction depend on the cell line used and the experimental practice (Schwartz et al., 2008; Suter and Krause, 2008; Daadi and Steinberg, 2009).

Two cell culture protocols are commonly used: suspension cultures and adherent cultures. In suspension, hPSCs form a cell mass. The most promising for 3D culture is in suspension. Adherent culture seems to provide better condition to obtain a homogenous cell population. An homogenous individual cell exposition to morphogens is not warranted due to the numerous cell layers. Thus, the concentration gradient can lead to the generation of cells at different developmental stages and subsequently the formation of multilayered structures that contain a heterogenous population of cells, including neural progenitors. The disadvantages of this protocol are: (1) the size of the cell mass varies, even with the same initial cell number and (2) there is variability in the percentage of each cell types generated and in the layer organization. In contrast, the adherent monolayer culture system allows a uniform cell exposition to morphogens and provides a more homogenous cell population. Static monolayer culture model does not mimic the in vivo microenvironment (Wilby et al., 1999) and none of the monolayer protocols used for cell differentiation yield structures and organization similar to those generated in suspension cultures or those with engineered neural tissues (ENTs).

\section{ENGINEERED NEURAL TISSUES}

The aim of hPSCs-derived neural tissue culture is to provide models for very early stage of nervous system development (neural tube and post neural tube early stages) and diseases, to provide models for toxicity and drug screening, and to explore the mechanism of action of different molecules. Three-dimensional cultures would allow for the study of interactions between various neural cell types and some intrinsic properties could be more readily compared with CNS physiological properties. To provide a relevant model for CNS modeling, the 3D culture system must adhere to three criteria: (1) to contain most CNS-related cell types (oligodendrocytes, neurons, astrocytes, microglia, endothelial cells, and meningeal fibroblasts); (2) to be biologically relevant (the in vitro system cell components must show similar behavior to those in vivo); (3) to recapitulate some of the developing or mature CNS features, including early neural tube organization. hPSC-derived ENTs have been produced by several laboratories with varying protocols and results (Wang et al., 2011). Amongst them, the use of air-liquid interface cell cultures device allows a 3D organization guided by endogenous developmental cues (Preynat-Seauve et al., 2009). Scaffolds with different materials like cellulose nanofibers, $\mathrm{SiO}_{2}$, PLGA nanofibers or silicon can also been used with or without coating. Some coatings increase neural differentiation. Some frequently used coating are the laminin to support neural adhesion, the poly-L-lysine, or the alginate gel to induce slow drug release (Leach et al., 2010). All of these in vitro models recapitulate, at least partly, in vivo nervous system development.

Tissue engineering may provide advanced in vitro models for drug testing in combination with non-destructive techniques for long-term studies. Cell proliferation, migration, differentiation, and synaptogenesis could be followed in ENTs and give precious information. ENTs could reduce time, cost, and number of animals necessary for pre-clinical studies. However, the tissue thickness and variety of cell types found in the hPSC-derived culture may be challenging. It is difficult to monitor cell morphology and phenotype during cell differentiation process in ENTs. Compared to cell derived in a monolayer, hPSCs derived in 3D cultures could provide a more elaborate system for developmental neurotoxicity testing. The research aim will determine the choice between the two culture methods (Figure 2).

\section{HUMAN CELL LINES AND IN VITRO MODELS}

Until recently, the human in vitro models available were limited to the use of transformed cell lines (like SH-SY5Y cells) or of primary cells obtained from aborted fetuses' tissues or from resection during brain surgery. Transformed or primary cell lines used have obvious limits (Table 2). (A). Transformed cell lines derived from tumors and do not represent normal neural cells (Breier et al., 2010). Human primary cell lines raise ethical problems, are difficult to obtain, and, in the case of adult brain biopsies, contain very few neural progenitors, neurons whose developmental processes is achieved, and many reactive astrocytes. On the other hand, fetal biopsies contain more neural progenitors, which is advantageous for culture systems. Biopsies from patients with a 


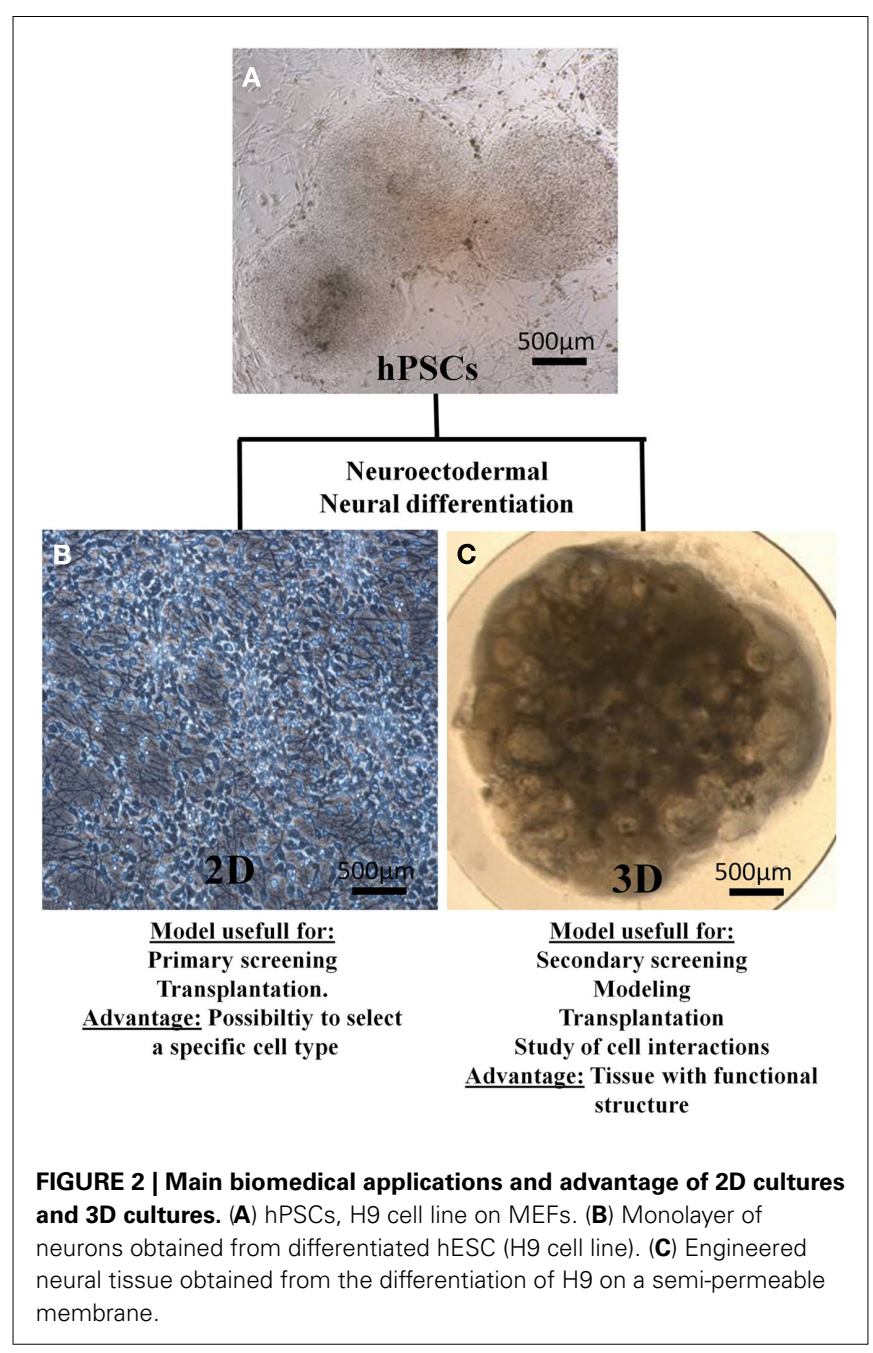

neurodegenerative disease or with epilepsy offer the opportunity to study real diseased human neurons (Radio and Mundy, 2008). Since recent developments of hIPS, especially hIPS from diseased humans, ethical problems are solved and hPSCs can now be considered a valuable tools for drug screening (Danovi et al., 2010).

NPCS derived from the H9 hESC line are commercially available ("Embryonic neural Stem-A" cells, Millipore, Inc.). Other neural stem cell lines are widely used by the research community such as ReNcell VM derived from the ventral mesencephalon or ReNcell CX derived from the cerebral cortex (ReNeuron group). To facilitate screening developments, these cells are defined by marketing features such as ideal culture and differentiation conditions, genomic stability, and phenotype expressed before and after differentiation. The recent production of hIPS from diseased patient represents a major advance for in vitro neurodegenerative disease models. The generation of in vitro assays with hPSCs facilitates early assessment of tested chemicals at a high throughput. Such assays become an area of interest for supporting "the 3 R's rule" (reduction, refinement, replacement) to alleviate animal use in biological research (Moors et al., 2009). The existing range of fundamental research protocols available to explore neural functioning allows investigation of all disease aspects. These protocols allow researchers to explore cellular phenotype (histological analysis), neuronal activity (electrophysiology, patch clamp, calcium imaging currents), connectivity (synapse maturation), circuitry (Rabies virus tracing, co-culture between neurons and glia), and cell migration (bioimaging).

\section{DRUG AND TOXICITY SCREENING WITH hPSCs}

The aim of drug screening is to find the most efficient molecule for a particular application, while avoiding deleterious effects. For efficient drug screening toxicity assessment, in vitro 3D culture models should yield a significant throughput. Because of their size and cell heterogeneity, these models are available only for the low-throughput approach. Considering the currently available protocols, it would be difficult to obtain the number of cultures required for regular use on 1536-well plates (Bal-Price et al., 2010).

The toxic properties of a large number of chemicals remain unknown, in particular in the CNS. hPSC-derived 3D systems could help to study the 1200 compounds known to be neurotoxic to humans or animals (non-confidential Toxic Substances Control Act, TSCA; Coecke et al., 2007). High-content/high-throughput screening (HCS/HTS) approaches to identify chemicals that may be toxic for nervous system cells are increasingly used (Lein et al., 2007; Breier et al., 2008). Present HCS/HTS approaches use imaging of biochemical or morphological endpoints in cells, such as neurite outgrowth, neurite number, average length, cell size, and shape, and nucleus/cytoplasm ratio (Pal et al., 2011). The use of hPSCs models in neurotoxicology and drug screening is an emerging field but that needs further expansion.

Although hPSCs are a reproducible and renewable source of cells, they do not offer all the main features required for screening, which are as follows: (1) It should be easy to produce the cell number needed to conduct HCS/HTS assays in multi-well plates; (2) Cell genotype and phenotype should be stable; (3) The proliferation, migration, and differentiation features of cells should be well-characterized and reproducible; (4) The relative percentage of neurons, astrocytes, and oligodendrocytes obtained during the differentiation should be standardized such that toxicity-induced changes in the proportions of each can be reliably detected (Breier et al., 2010). hPSCs do not satisfy to all of these characteristics. The major problems for their use in screening are: (1) The maintenance of stem cell colonies is an intensive and expensive labor; (2) Exact medium composition is rarely known because of commercial protections; (3) The time needed to accomplish neuronal differentiation is very long; (4) The conditions required for specific neuronal differentiation are not fully elucidated; (5) The neural progeny is asynchronous: mature and immature neural cell types are present in the final cell population (Breier et al., 2010; Azari et al., 2011). The above disadvantages explain why until now neurons derived from hPSCs have been rarely used to test the efficacy of drugs and their neurotoxicity (Barbaric et al., 2010). Recent hIPS-derived neuronal modeling establish alternatives tools for current drug screening platforms, at least as proof-of-principle (Ebert et al., 2009). Foremost, among hIPS derived from diseased patients' neural cells make it possible to target the screening against a specific disease. In some cases, such as with schizophrenia, screening could be complicated (Brennand et al., 2011). The complexity of this disease would require a subgrouping of hIPS based on pathways that are impacted for each specific patient. On 
Table 2 | Cell types used in biomedical research with their advantages and inconvenients.

\begin{tabular}{|c|c|c|}
\hline Cell types & Advantage & Disadvantage \\
\hline \multirow[t]{3}{*}{ Immortalized cell lines } & Easy to obtain large quantities & Different from in vivo cells \\
\hline & Inexpensive & Modified cell lines \\
\hline & & Relevance limited \\
\hline \multirow[t]{2}{*}{ Primary cell culture } & Relevance & Hard to obtain \\
\hline & Behavior similar to in vivo & Limited quantities \\
\hline \multirow[t]{4}{*}{ hESC } & Unlimited quantities & Ethical issues \\
\hline & Unmodified cells & Expensive \\
\hline & & Long differentiation time \\
\hline & & Cell lines hard to obtain \\
\hline \multirow[t]{2}{*}{ hIPS } & Close to in vivo reality & Expensive \\
\hline & Cell lines from patient with specific diseases easy to obtain & Not yet proven to have complete equivalence with hESC \\
\hline \multirow[t]{2}{*}{ Transdifferentiated cells } & Relevance & Limited quantities \\
\hline & Ability to obtain one specific cell type & Impact of transdifferentiation not well known \\
\hline
\end{tabular}

Table 3 |A specific cell type for a specific disease.

\begin{tabular}{|c|c|c|}
\hline Target cell population & Markers & Potential treatment \\
\hline NPC & Musashi, Nestin, Sox 2, Vimentin, Pax6, Sox1 & \\
\hline Astrocytes & GFAP, S100, Ran2 & \\
\hline Oligodendrocytes & 01, O2, MBP, RIP, CNPase, GalC & Vascular neuroencephalopaties, multiple sclerosis \\
\hline GABA neurons & GABA, DARPP-32, GAD, VGAT & Huntington's disease \\
\hline Dopamin neurons & DBH, DAT, I-DOPA, TH & Parkinson's disease \\
\hline Cholinergic neurons & Acetylcholinesterase, ACh, ChAT, choline transporter & Alzheimer's disease \\
\hline Motor neurons & ChAT, Chox10, En1, Evx1/2, Islet1/2, Lim3, REG2, Sim1 & Amyotrophic lateral sclerosis, spinal cord injury \\
\hline Auditory neural lineage & GATA3, phosphorylated NFH within Somata & Hearing loss (cochlear implant; Gunewardene et al., 2011) \\
\hline Retinal cell lineage & Rhodopsin, RBP3 & Blindness (Bharti et al., 2011) \\
\hline
\end{tabular}

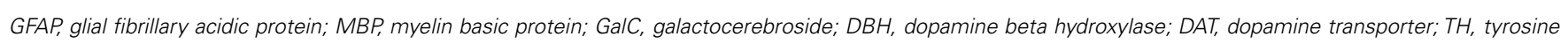
hydroxylase; SERT, serotonin transporter; Ach, acetylcholine; ChAT, choline acetyltransferase; RBP3, retinol binding protein 3.

the other hand, hIPS could bring the opportunity to identify the specific molecular factors in each subgroup. In this way, hIPS could hold the promise of individualized medicine in complex disease (Brennand et al., 2011; Buxbaum and Sklar, 2011).

\section{hPSCs THERAPIES FOR NEURAL TISSUE REPLACEMENT}

Effective treatments do not exist for neurodegenerative diseases. hPSCs hold enormous promise for cell-replacement based therapies. They are a potentially unlimited source of allogenic or autologous cells. The main goal of treatment-oriented research is to obtain appropriate cells able to repopulate diseased tissue in vivo without deleterious consequences. Cells must be free from xeno-contamination to avoid risks of zoonosis or activation of animal retroviruses (Swistowski et al., 2009). Then, appropriate cell differentiation and selection are critical to obtain enough specific cells to treat a targeted disease such as Parkinson's disease or Alzheimer's disease (Table 3). (B). The strict phenotype specificity and purity of transplanted cells is an absolute requirement.

One of the major problems is the teratoma, or overgrowth risk. It remains to be solved for most of the potential treatments. Following neural differentiation, neural precursors are able to proliferate in an uncontrolled manner, even if all of the undifferentiated cells are removed. For example, in a recent experiment, grafted IPS derived to striatal spiny neurons overgrew and lead to deleterious side effects after 13 weeks. The overgrowth problem was due to some nestin-positive NPCs and not to the presence of undifferentiated ESCs (Aubry et al., 2008). Three different ways have been investigated to increase transplantation efficiency as well as to avoid overgrowth or teratoma formation: (1) Cell sorting to isolate a specific population; (2) hPSC lines modified with an inducible suicide gene under the control of a promoter element used to maintain "stemness" (Schuldiner et al., 2003); (3) Targeted anti-human hPSC antibodies that induce apoptosis of undifferentiated hPSC (Choo et al., 2008; Tan et al., 2009; Lim et al., 2011). Finally, as with all transplantations, the risk of rejection must be considered (Preynat-Seauve and Krause, 2011).

With the aim to develop knowledge and potential therapies, many IPS lines have been produced from patient suffering from a variety of neurological diseases like HD, PD (Park et al., 2008), SMA (Ebert et al., 2009), ALS (Dimos et al., 2008), and schizophrenia (Chiang et al., 2011). "Proof-of-concept" for cell replacement therapy has been provided in the following two examples: PD and spinal cord injury (SCI; Roy et al., 2006; Erceg et al., 2010). 


\section{PARKINSON'S DISEASE}

First described in 1817 by James Parkinson, this degenerative disorder results from the death of dopaminergic neurons in the ventral midbrain substantia nigra (Goto et al., 1990). The prevalence of Parkinson's disease (PD) is about $1-2 \%$ of the population over 65 years (Alves et al., 2008). Symptoms are severe motor deficits like muscle rigidity, tremors, and unstable gait and posture. Current treatments consists of the administration of drug levodopa (L-dopa), a dopamine precursor able to cross the blood-brain barrier and be metabolized into dopamine (Sethi, 2010). Deep brain stimulations are also used (Tuszynski, 2007). However, these treatments only alleviate symptoms; they do not correct deficits and are progressively ineffective with PD progression. Furthermore, long-term use of $\mathrm{L}$-dopa induces dyskinesia (Calabresi et al., 2010). Research for more efficient alternative treatments are currently being investigated. Transplantation of neurons from fetal ventral midbrain to replace lost dopamine neurons shows varied and sometimes no benefit for the patients in clinical trials (Freed et al., 2001; Olanow et al., 2003). Moreover, due to ethical concerns and the difficulties in obtaining adequate tissue, this alternative will likely remain marginal. There has been progress in other areas though; hPSCs derived to dopaminergic neurons and then transplanted into a rat model of Parkinson's disease produced improvements in motor function (Ben-Hur et al., 2004; Roy et al., 2006; Chiba et al., 2008). As techniques have progressed to the point that researchers can obtain pure dopaminergic neurons from hPSCs (Cho et al., 2008; Swistowski et al., 2010; Kim, 2011). Moreover, derivation of specific dopaminergic neurons from patient IPS has been achieved and transplantation of these cells into a rodent PD model showed an alleviation of motor deficits (Cooper et al., 2010; Hargus et al., 2010). All together, these studies show that hPSCs are promising candidates for cell replacement therapy.

\section{SPINAL CORD INJURY}

The most advanced hPSC-derived therapy aims to treat SCI. It is the first treatment to be evaluated in clinical trials (Geron Corporation, 2009). This trial has been halted for economic reasons by Geron enterprise but continue to be monitored. In United States, incidence of SCI is estimated to be about 12,000 cases each year (Qin et al., 2010). After a spinal cord trauma, symptoms can vary depending on the localization of the damages as well as various internal and external factors (Jagatsinh, 2009). To treat motor deficit related to SCI the connection between motor cortex and muscles must be restored. For this purpose, the transplantation of motor neurons and oligodendrocytes can be considered. These two cells types can be derived from hPSCs (Kerr et al., 2010) and hPSCs induced to motor neurons promote functional recovery after SCI in a rat model (Rossi et al., 2010). Tissue engineering approaches has been tested to treat SCI. They combine hPSCs with collagen or fibrin-based scaffold. These scaffolds are able to deliver growth factors promoting hPSCs differentiation into oligodendrocytes and neurons. (Hatami et al., 2009; Johnson et al., 2010). These studies showed that implanted cells increase locomotor functions and enhance functional recovery in a rat model of SCI (Kerr et al., 2010; Niapour et al., 2011; Lee et al., 2012).

\section{OTHER INJURIES AND DISEASES}

Another promising trial is for Huntington's disease (HD), a neurodegenerative genetic disorder that causes dementia and affects muscle coordination. Prevalence of this disease is about $0.01 \%$ of the population (Warren and Yellowlees, 1990). As for PD, some studies have investigated the potential of fetal tissue transplantation as treatment and show more encouraging results for HD treatment than for PD treatment (Frank and Biglan, 2007; Gallina et al., 2010). Another experiment involved differentiation hIPS into neural progenitors and transplanting them into a rat model of HD; grafted animals had better performance than controls (Song et al., 2007). Unfortunately, in these tests, the mechanism of recovery was not clear: was it due to factors released by the graft or by the host tissue?

Human pluripotent stem cells were also occasionally used for traumatic brain injury and Alzheimer's disease (Molcanyi et al., 2007; Moghadam et al., 2009). Cell replacement therapy could be also investigated in some case of severe epilepsies by implantation of specific GABAergic neurons directly into affected areas. Most of these studies use mouse models and embryonic stem cells (mESCs), so much work would need to be repeated with hESC in pre-clinical testing to determine the viability of such therapies (Wang et al., 2006; Riess et al., 2007).

\section{CONCLUSION}

Despite the recurring front page media stories about hPSCs and therapeutic promises, we are still many years from clinical applications. hPSCs provide a renewable source of all somatic cell types, but important difficulties remain. The main ones stay to isolate and have a long-term expansion of specific cells. To achieve specific hPSCs differentiation requires protocols that are often complicated and expensive. Current cell selection protocols have intrinsic limits and cell cultures may still yield mixed populations containing neural cells at different developmental stages, which necessarily limits biomedical applications needing well-defined cells (Ebert and Svendsen, 2010). The recent development of hIPS allows generation of patient-specific neural cells and tissue, but we still do not know if these cells are equivalent to hESC since their respective potential can differ (Martinez-Fernandez et al., 2011).

The number of genetic mutations that are induced by the return to pluripotency can hamper future applications. Moreover, in the case of age-dependent diseases like HD, hIPS-derived cells do not always exhibit phenotypic differences compared with normal control cells. Some newer protocols involve culturing cells under oxidative stress conditions to reveal or accelerate aberrant neuronal phenotypes in late-onset diseases, but their relevance in drug screening is not yet established (Nguyen et al., 2011; Seibler et al., 2011). The use of hIPS in modeling diseases like Timothy syndrome or Down syndrome is only just beginning, and much work remains to obtain relevant models (Yazawa et al., 2011). Despites these limits, hPSCs have the potential to improve our knowledge in many biomedical domains. For example, hPSCs have obvious applications in neuroprostethics, leading to a better understanding of the inflammation process following implantation. Also, if performed early in the drug development process by pharmaceutical companies, relevant toxicological screenings would allow a substantial decrease in the cost of clinical studies. Moreover, the 
introduction of hIPS adds a "personalized medicine" dimension to eventual biomedical applications. Considering these potential advantages, hPSCs are full of promise in the near future.

\section{REFERENCES}

Alves, G., Forsaa, E. B., Pedersen, K. F., Dreetz Gjerstad, M., and Larsen, J. P. (2008). Epidemiology of Parkinson's disease. J. Neurol. 255(Suppl. 5), 18-32.

Anokye-Danso, F., Trivedi, C. M., Juhr, D., Gupta, M., Cui, Z., Tian, Y., Zhang, Y., Yang, W., Gruber, P. J., Epstein, J. A., and Morrisey, E. E. (2011). Highly efficient miRNAmediated reprogramming of mouse and human somatic cells to pluripotency. Cell Stem Cell 8, 376-388.

Aubry, L., Bugi, A., Lefort, N., Rousseau, F., Peschanski, M., and Perrier, A. L. (2008). Striatal progenitors derived from human ES cells mature into DARPP32 neurons in vitro and in quinolinic acid-lesioned rats. Proc. Natl. Acad. Sci. U.S.A. 105, 16707-16712.

Azari, H., Osborne, G. W., Yasuda, T., Golmohammadi, M. G., Rahman, M., Deleyrolle, L. P., Esfandiari, E., Adams, D. J., Scheffler, B., Steindler, D. A., and Reynolds, B. A. (2011). Purification of immature neuronal cells from neural stem cell progeny. PLoS ONE 6, e20941. doi:10.1371/journal.pone.0020941

Aznar, J., and Sanchez, J. L. (2011). Embryonic stem cells: are useful in clinic treatments? J. Physiol. Biochem. 67, 141-144.

Baek, K. H., Zaslavsky, A., Lynch, R. C., Britt, C., Okada, Y., Siarey, R. J., Lensch, M. W., Park, I. H., Yoon, S. S., Minami, T., Korenberg, J. R., Folkman, J., Daley, G. Q., Aird, W. C., Galdzicki, Z., and Ryeom, S. (2009). Down's syndrome suppression of tumour growth and the role of the calcineurin inhibitor DSCR1. Nature 459, 1126-1130.

Bal-Price, A. K., Hogberg, H. T., Buzanska, L., Lenas, P., Van Vliet, E., and Hartung, T. (2010). In vitro developmental neurotoxicity (DNT) testing: relevant models and endpoints. Neurotoxicology 31, 545-554.

Barbaric, I., Gokhale, P. J., and Andrews, P. W. (2010). High-content screening of small compounds on human embryonic stem cells. Biochem. Soc. Trans. 38, 1046-1050.

Barrett, R. D., Bennet, L., Davidson, J., Dean, J. M., George, S., Emerald, B. S., and Gunn, A. J. (2007). Destruction and reconstruction: hypoxia and the developing brain. Birth Defects Res. C Embryo Today 81, 163-176.

Ben-Hur, T., Idelson, M., Khaner, H., Pera, M., Reinhartz, E., Itzik, A., and
Reubinoff, B. E. (2004). Transplantation of human embryonic stem cellderived neural progenitors improves behavioral deficit in Parkinsonian rats. Stem Cells 22, 1246-1255.

Bharti, K., Miller, S. S., and Arnheiter, H. (2011). The new paradigm: retinal pigment epithelium cells generated from embryonic or induced pluripotent stem cells. Pigment Cell Melanoma Res. 24, 21-34.

Bhattacharya, B., Puri, S., and Puri, R. K. (2009). A review of gene expression profiling of human embryonic stem cell lines and their differentiated progeny. Curr. Stem Cell Res. Ther. 4, 98-106.

Bock, C., Kiskinis, E., Verstappen, G., Gu, H., Boulting, G., Smith, Z. D., Ziller, M., Croft, G. F., Amoroso, M. W., Oakley, D. H., Gnirke, A., Eggan, K., and Meissner, A. (2011). Reference Maps of human ES and iPS cell variation enable high-throughput characterization of pluripotent cell lines. Cell 144, 439-452.

Breier, J. M., Gassmann, K., Kayser, R., Stegeman, H., De Groot, D., Fritsche, E., and Shafer, T. J. (2010). Neural progenitor cells as models for highthroughput screens of developmental neurotoxicity: state of the science. Neurotoxicol. Teratol. 32, 4-15.

Breier, J. M., Radio, N. M., Mundy, W. R., and Shafer, T. J. (2008). Development of a high-throughput screening assay for chemical effects on proliferation and viability of immortalized human neural progenitor cells. Toxicol. Sci. 105, 119-133.

Brennand, K. J., Simone, A., Jou, J., Gelboin-Burkhart, C., Tran, N., Sangar, S., Li, Y., Mu, Y., Chen, G., Yu, D., Mccarthy, S., Sebat, J., and Gage, F. H. (2011). Modelling schizophrenia using human induced pluripotent stem cells. Nature 473, 221-225.

Buxbaum, J. D., and Sklar, P. (2011). Human induced pluripotent stem cells: a new model for schizophrenia? Cell Stem Cell 8, 461-462.

Calabresi, P., Di Filippo, M., Ghiglieri, V., Tambasco, N., and Picconi, B. (2010). Levodopa-induced dyskinesias in patients with Parkinson's disease: filling the bench-to-bedside gap. Lancet Neurol. 9, 1106-1117.

Chiang, C. H., Su, Y., Wen, Z., Yoritomo, N., Ross, C. A., Margolis, R. L., Song, H., and Ming, G. L. (2011). Integration-free induced pluripotent stem cells derived from schizophrenia patients with a DISC1

\section{ACKNOWLEDGMENTS}

We thank the Clayton foundation and the FNRS-Sinergia (No. 125408) for financial support.

mutation. Mol. Psychiatry 16, 358-360.

Chiba, S., Lee, Y. M., Zhou, W., and Freed, C. R. (2008). Noggin enhances dopamine neuron production from human embryonic stem cells and improves behavioral outcome after transplantation into Parkinsonian rats. Stem Cells 26, 2810-2820.

Cho, M. S., Hwang, D. Y., and Kim, D. W. (2008). Efficient derivation of functional dopaminergic neurons from human embryonic stem cells on a large scale. Nat. Protoc. 3, 1888-1894.

Choo, A. B., Tan, H. L., Ang, S. N., Fong, W. J., Chin, A., Lo, J., Zheng, L., Hentze, H., Philp, R. J., Oh, S. K. and Yap, M. (2008). Selection against undifferentiated human embryonic stem cells by a cytotoxic antibody recognizing podocalyxin-like protein-1. Stem Cells 26, 1454-1463.

Coecke, S., Goldberg, A. M., Allen, S., Buzanska, L., Calamandrei, G., Crofton, K., Hareng, L., Hartung, T., Knaut, H., Honegger, P., Jacobs, M. Lein, P., Li, A., Mundy, W., Owen, D. Schneider, S., Silbergeld, E., Reum, T., Trnovec, T., Monnet-Tschudi, F., and Bal-Price, A. (2007). Workgroup report: incorporating in vitro alternative methods for developmental neurotoxicity into international hazard and risk assessment strategies. Environ. Health Perspect. 115, 924-931.

Cooper, O., Hargus, G., Deleidi, M., Blak, A., Osborn, T., Marlow, E., Lee, K., Levy, A., Perez-Torres, E., Yow, A., and Isacson, O. (2010). Differentiation of human ES and Parkinson's disease iPS cells into ventral midbrain dopaminergic neurons requires a high activity form of $\mathrm{SHH}$ FGF8a and specific regionalization by retinoic acid. Mol. Cell. Neurosci. 45, 258-266.

Daadi, M. M., and Steinberg, G. K. (2009). Manufacturing neurons from human embryonic stem cells: biological and regulatory aspects to develop a safe cellular product for stroke cell therapy. Regen. Med. 4, 251-263.

Danovi, D., Falk, A., Humphreys, P., Vickers, R., Tinsley, J., Smith, A. G., and Pollard, S. M. (2010). Imagingbased chemical screens using normal and glioma-derived neural stem cells. Biochem. Soc. Trans. 38, 1067-1071.

Dantuma, E., Merchant, S., and Sugaya, K. (2010). Stem cells for the treatment of neurodegenerative diseases. Stem Cell Res. Ther. 1, 37.

Deep-Soboslay, A., Benes, F. M., Haroutunian, V., Ellis, J. K., Kleinman, J. E., and Hyde, T. M. (2011). Psychiatric brain banking: three perspectives on current trends and future directions. Biol. Psychiatry 69, 104-112.

Dhara, S. K., and Stice, S. L. (2008) Neural differentiation of human embryonic stem cells. J. Cell. Biochem. 105, 633-640.

Dimos, J. T., Rodolfa, K. T., Niakan, K. K., Weisenthal, L. M., Mitsumoto, H., Chung, W., Croft, G. F., Saphier, G., Leibel, R., Goland, R., Wichterle, H., Henderson, C. E., and Eggan, K. (2008). Induced pluripotent stem cells generated from patients with ALS can be differentiated into motor neurons. Science 321 , 1218-1221.

Ding, Y. X., Wei, L. C., Wang, Y. Z. Cao, R., Wang, X., and Chen, L. W. (2011). Molecular manipulation targeting regulation of dopaminergic differentiation and proliferation of neural stem cells or pluripotent stem cells. CNS Neurol. Disord. Drug Targets 10, 517-528.

Ebert, A. D., and Svendsen, C. N. (2010). Human stem cells and drug screening: opportunities and challenges. Nat. Rev. Drug Discov. 9, 367-372.

Ebert, A. D., Yu, J., Rose, F. F., Jr., Mattis, V. B., Lorson, C. L., Thomson, J. A., and Svendsen, C. N. (2009). Induced pluripotent stem cells from a spinal muscular atrophy patient. Nature 457, 277-280.

Erceg, S., Ronaghi, M., Oria, M., Rosello, M. G., Arago, M. A., Lopez, M. G., Radojevic, I., MorenoManzano, V., Rodriguez-Jimenez, F. J., Bhattacharya, S. S., Cordoba, J., and Stojkovic, M. (2010). Transplanted oligodendrocytes and motoneuron progenitors generated from human embryonic stem cells promote locomotor recovery after spinal cord transection. Stem Cells 28, 1541-1549.

Frank, S., and Biglan, K. (2007). Longterm fetal cell transplant in Huntington disease: stayin' alive. Neurology 68, 2055-2056.

Freed, C. R., Greene, P. E., Breeze, R. E., Tsai, W. Y., Dumouchel, W., Kao, R., Dillon, S., Winfield, H., Culver, S., Trojanowski, J. Q., Eidelberg, D., and Fahn, S. (2001). Transplantation of embryonic dopamine neurons for severe Parkinson's disease. N. Engl. J. Med. 344, 710-719. 
Gallina, P., Paganini, M., Lombardini, L., Mascalchi, M., Porfirio, B., Gadda, D., Marini, M., Pinzani, P., Salvianti, F., Crescioli, C., Bucciantini, S., Mechi, C., Sarchielli, E., Romoli, A. M., Bertini, E., Urbani, S., Bartolozzi, B., De Cristofaro, M. T., Piacentini, S., Saccardi, R., Pupi, A., Vannelli, G. B., and Di Lorenzo, N. (2010). Human striatal neuroblasts develop and build a striatal-like structure into the brain of Huntington's disease patients after transplantation. Exp. Neurol. 222, 30-41.

Geron Corporation. (2009). World's first clinical trial of human embryonic stem cell therapy cleared. Regen. Med. 4, 161.

Gonzalez, F., Boue, S., and Izpisua Belmonte, J. C. (2011). Methods for making induced pluripotent stem cells: reprogramming a la carte. Nat. Rev. Genet. 12, 231-242.

Goto, S., Hirano, A., and Matsumoto, S. (1990). Immunohistochemical study of the striatal efferents and nigral dopaminergic neurons in parkinsonism-dementia complex on Guam in comparison with those in Parkinson's and Alzheimer's diseases. Ann. Neurol. 27, 520-527.

Gunewardene, N., Dottori, M., and Nayagam, B. A. (2011). The convergence of cochlear implantation with induced pluripotent stem cell therapy. Stem Cell Rev. PMID: 21956409. [Epub ahead of print].

Hargus, G., Cooper, O., Deleidi, M., Levy, A., Lee, K., Marlow, E., Yow, A., Soldner, F., Hockemeyer, D., Hallett, P. J., Osborn, T., Jaenisch, R., and Isacson, O. (2010). Differentiated Parkinson patient-derived induced pluripotent stem cells grow in the adult rodent brain and reduce motor asymmetry in Parkinsonian rats. Proc. Natl. Acad. Sci. U.S.A. 107, 15921-15926.

Hatami, M., Mehrjardi, N. Z., Kiani, S., Hemmesi, K., Azizi, H., Shahverdi, A., and Baharvand, H. (2009). Human embryonic stem cell-derived neural precursor transplants in collagen scaffolds promote recovery in injured rat spinal cord. Cytotherapy $11,618-630$.

Hochedlinger, K., and Jaenisch, R. (2006). Nuclear reprogramming and pluripotency. Nature 441, 1061-1067.

Hotta, A., Cheung, A. Y., Farra, N., Garcha, K., Chang, W. Y., Pasceri, P., Stanford, W. L., and Ellis, J. (2009). EOS lentiviral vector selection system for human induced pluripotent stem cells. Nat. Protoc. 4, 1828-1844.

Huangfu, D., Osafune, K., Maehr, R., Guo, W., Eijkelenboom, A., Chen,
S., Muhlestein, W., and Melton, D. A. (2008). Induction of pluripotent stem cells from primary human fibroblasts with only Oct4 and Sox2. Nat. Biotechnol. 26, 1269-1275.

Jagatsinh, Y. (2009). Intrathecal baclofen: Its effect on symptoms and activities of daily living in severe spasticity due to spinal cord injuries: A pilot study. Indian J. Orthop. 43, 46-49.

Johnson, P. J., Tatara, A., Mccreedy, D. A., Shiu, A., and Sakiyama-Elbert, S. E. (2010). Tissue-engineered fibrin scaffolds containing neural progenitors enhance functional recovery in a subacute model of SCI. Soft Matter 6, 5127-5137.

Kawaguchi, D., Yoshimatsu, T., Hozumi, K., and Gotoh, Y. (2008). Selection of differentiating cells by different levels of delta-like 1 among neural precursor cells in the developing mouse telencephalon. Development 135, 3849-3858.

Kerr, C. L., Letzen, B. S., Hill, C. M., Agrawal, G., Thakor, N. V., Sterneckert, J. L., Gearhart, J. D., and All, A. H. (2010). Efficient differentiation of human embryonic stem cells into oligodendrocyte progenitors for application in a rat contusion model of spinal cord injury. Int. J. Neurosci. $120,305-313$

Kim, H. J. (2011). Stem cell potential in Parkinson's disease and molecular factors for the generation of dopamine neurons. Biochim. Biophys. Acta 1812, 1-11.

Kim, J., Efe, J. A., Zhu, S., Talantova, M., Yuan, X., Wang, S., Lipton, S. A., Zhang, K., and Ding, S. (2011). Direct reprogramming of mouse fibroblasts to neural progenitors. Proc. Natl. Acad. Sci. U.S.A. 108, 7838-7843.

Leach, J. B., Achyuta, A. K., and Murthy, S. K. (2010). Bridging the divide between neuroprosthetic design, tissue engineering and neurobiology. Front. Neuroengineering 2:18. doi:10.3389/neuro.16.018.2009

Lee, G., Papapetrou, E. P., Kim, H., Chambers, S. M., Tomishima, M. J., Fasano, C. A., Ganat, Y. M., Menon, J., Shimizu, F., Viale, A., Tabar, V., Sadelain, M., and Studer, L. (2009). Modelling pathogenesis and treatment of familial dysautonomia using patient-specific iPSCs. Nature 461, 402-406.

Lee, K. B., Choi, J. H., Byun, K., Chung, K. H., Ahn, J. H., Jeong, G. B., Hwang, I. K., Kim, S., Won, M. H., and Lee, B. (2012). Recovery of CNS pathway innervating the sciatic nerve following transplantation of human neural stem cells in rat spinal cord injury. Cell. Mol. Neurobiol. 32, 149-157.

Lees, J. G., Lim, S. A., Croll, T., Williams, G., Lui, S., Cooper-White, J., Mcquade, L. R., Mathiyalagan, B., and Tuch, B. E. (2007). Transplantation of 3D scaffolds seeded with human embryonic stem cells: biological features of surrogate tissue and teratoma-forming potential. Regen. Med. 2, 289-300.

Lein, P., Locke, P., and Goldberg, A. (2007). Meeting report: alternatives for developmental neurotoxicity testing. Environ. Health Perspect. $115,764-768$.

Li, M. (2002). Lineage selection for generation and amplification of neural precursor cells. Methods Mol. Biol. $185,205-215$

Li, W., Sun, W., Zhang, Y., Wei, W., Ambasudhan, R., Xia, P., Talantova, M., Lin, T., Kim, J., Wang, X., Kim, W. R., Lipton, S. A., Zhang, K., and Ding, S. (2011). Rapid induction and long-term self-renewal of primitive neural precursors from human embryonic stem cells by small molecule inhibitors. Proc. Natl. Acad. Sci. U.S.A. 108, 8299-8304.

Lim, D. Y., Ng, Y. H., Lee, J., Mueller, M., Choo, A. B., and Wong, V. V. (2011) Cytotoxic antibody fragments for eliminating undifferentiated human embryonic stem cells. J. Biotechnol. $153,77-85$.

Marchetto, M. C., Winner, B., and Gage, F. H. (2010). Pluripotent stem cells in neurodegenerative and neurodevelopmental diseases. Hum. Mol. Genet. 19, R71-R76.

Martinez-Fernandez, A., Nelson, T. J., and Terzic, A. (2011). Nuclear reprogramming strategy modulates differentiation potential of induced pluripotent stem cells. J. Cardiovasc. Transl. Res. 4, 131-137.

Martinez, Y., Bena, F., Gimelli, S., Tirefort, D., Dubois-Dauphin, M. Krause, K. H., and Preynat-Seauve, O. (2011). Cellular diversity within embryonic stem cells: pluripotent clonal sublines show distinct differentiation potential. J. Cell. Mol. Med. $16,456-467$.

Moghadam, F. H., Alaie, H., Karbalaie, K., Tanhaei, S., Nasr Esfahani, M. H., and Baharvand, H. (2009). Transplantation of primed or unprimed mouse embryonic stem cell-derived neural precursor cells improves cognitive function in Alzheimerian rats. Differentiation 78, 59-68.

Molcanyi, M., Riess, P., Bentz, K., Maegele, M., Hescheler, J., Schafke, B., Trapp, T., Neugebauer, E., Klug, N., and Schafer, U. (2007). Traumaassociated inflammatory response impairs embryonic stem cell survival and integration after implantation into injured rat brain. J. Neurotrauma 24, 625-637.

Moors, M., Rockel, T. D., Abel, J., Cline, J. E., Gassmann, K., Schreiber, T. Schuwald, J., Weinmann, N., and Fritsche, E. (2009). Human neurospheres as three-dimensional cellular systems for developmental neurotoxicity testing. Environ. Health Perspect. 117, 1131-1138.

Nat, R., and Hovatta, O. (2004). In vitro neural differentiation of human embryonic stem cells. J. Cell. Mol. Med. 8, 570-571.

Nguyen, H. N., Byers, B., Cord, B., Shcheglovitov, A., Byrne, J., Gujar, P., Kee, K., Schule, B., Dolmetsch, R. E., Langston, W., Palmer, T. D., and Pera, R. R. (2011). LRRK2 mutant iPSCderived DA neurons demonstrate increased susceptibility to oxidative stress. Cell Stem Cell 8, 267-280.

Niapour, A., Karamali, F., Nemati, S., Taghipour, Z., Mardani, M., NasrEsfahani, M. H., and Baharvand, H. (2011). Co-transplantation of human embryonic stem cell-derived neural progenitors and schwann cells in a rat spinal cord contusion injury model elicits a distinct neurogenesis and functional recovery. Cell Transplant. PMID: 21944670. [Epub ahead of print].

Ohi, Y., Qin, H., Hong, C., Blouin, L. Polo, J. M., Guo, T., Qi, Z., Downey, S. L., Manos, P. D., Rossi, D. J., Yu, J., Hebrok, M., Hochedlinger, K., Costello, J. F., Song, J. S., and Ramalho-Santos, M. (2011). Incomplete DNA methylation underlies a transcriptional memory of somatic cells in human iPS cells. Nat. Cell Biol. 13, 541-549.

Okita, K., Matsumura, Y., Sato, Y., Okada, A., Morizane, A., Okamoto, S., Hong, H., Nakagawa, M., Tanabe, K., Tezuka, K., Shibata, T., Kunisada, T., Takahashi, M., Takahashi, J., Saji, H., and Yamanaka, S. (2011). A more efficient method to generate integration-free human iPS cells. Nat. Methods 8, 409-412.

Olanow, C. W., Goetz, C. G., Kordower, J. H., Stoessl, A. J., Sossi, V., Brin, M. F., Shannon, K. M., Nauert, G. M., Perl, D. P., Godbold, J., and Freeman, T. B. (2003). A doubleblind controlled trial of bilateral fetal nigral transplantation in Parkinson's disease. Ann. Neurol. 54, 403-414.

Pal, R., Mamidi, M. K., Das, A. K., and Bhonde, R. (2011). Human embryonic stem cell proliferation and differentiation as parameters to evaluate developmental toxicity. J. Cell. Physiol. 226, 1583-1595. 
Pang, Z. P., Yang, N., Vierbuchen, T., Ostermeier, A., Fuentes, D. R., Yang, T. Q., Citri, A., Sebastiano, V., Marro, S., Sudhof, T. C., and Wernig, M. (2011). Induction of human neuronal cells by defined transcription factors. Nature 476, 220-223.

Pankratz, M. T., Li, X. J., Lavaute, T. M., Lyons, E. A., Chen, X., and Zhang, S. C. (2007). Directed neural differentiation of human embryonic stem cells via an obligated primitive anterior stage. Stem Cells 25, 1511-1520.

Park, I. H., Arora, N., Huo, H., Maherali, N., Ahfeldt, T., Shimamura, A., Lensch, M. W., Cowan, C., Hochedlinger, K., and Daley, G. Q. (2008). Disease-specific induced pluripotent stem cells. Cell 134, 877-886.

Pfisterer, U., Kirkeby, A., Torper, O., Wood, J., Nelander, J., Dufour, A., Bjorklund, A., Lindvall, O., Jakobsson, J., and Parmar, M. (2011). Direct conversion of human fibroblasts to dopaminergic neurons. Proc. Natl. Acad. Sci. U.S.A. 108, 10343-10348.

Preynat-Seauve, O., and Krause, K. H. (2011). Stem cell sources for regenerative medicine: the immunological point of view. Semin. Immunopathol. $33,519-524$.

Preynat-Seauve, O., Suter, D. M., Tirefort, D., Turchi, L., Virolle, T., Chneiweiss, H., Foti, M., Lobrinus, J. A., Stoppini, L., Feki, A., Dubois-Dauphin, M., and Krause, K. H. (2009). Development of human nervous tissue upon differentiation of embryonic stem cells in threedimensional culture. Stem Cells 27, 509-520.

Qin, W., Bauman, W. A., and Cardozo, C. (2010). Bone and muscle loss after spinal cord injury: organ interactions. Ann. N. Y. Acad. Sci. 1211, 66-84.

Radio, N. M., and Mundy, W. R. (2008). Developmental neurotoxicity testing in vitro: models for assessing chemical effects on neurite outgrowth. Neurotoxicology 29, 361-376.

Reubinoff, B. E., Itsykson, P., Turetsky, T., Pera, M. F., Reinhartz, E., Itzik, A., and Ben-Hur, T. (2001). Neural progenitors from human embryonic stem cells. Nat. Biotechnol. 19, 1134-1140.

Riess, P., Molcanyi, M., Bentz, K., Maegele, M., Simanski, C., Carlitscheck, C., Schneider, A., Hescheler, J., Bouillon, B., Schafer, U., and Neugebauer, E. (2007). Embryonic stem cell transplantation after experimental traumatic brain injury dramatically improves neurological outcome, but may cause tumors. $J$. Neurotrauma 24, 216-225.
Rossi, S. L., Nistor, G., Wyatt, T., Yin, H. Z., Poole, A. J., Weiss, J. H., Gardener, M. J., Dijkstra, S., Fischer, D. F., and Keirstead, H. S. (2010). Histological and functional benefit following transplantation of motor neuron progenitors to the injured rat spinal cord. PLoS ONE 5, e11852. doi:10.1371/journal.pone.0011852

Roy, N. S., Cleren, C., Singh, S. K., Yang, L., Beal, M. F., and Goldman, S. A. (2006). Functional engraftment of human ES cell-derived dopaminergic neurons enriched by coculture with telomerase-immortalized midbrain astrocytes. Nat. Med. 12, 1259-1268.

Sasai, N., Yakura, R., Kamiya, D., Nakazawa, Y., and Sasai, Y. (2008). Ectodermal factor restricts mesoderm differentiation by inhibiting p53. Cell 133, 878-890.

Schuldiner, M., Itskovitz-Eldor, J., and Benvenisty, N. (2003). Selective ablation of human embryonic stem cells expressing a "suicide" gene. Stem Cells 21, 257-265.

Schwartz, P. H., Brick, D. J., Stover, A. E., Loring, J. F., and Muller, F. J. (2008). Differentiation of neural lineage cells from human pluripotent stem cells. Methods 45, 142-158.

Seibler, P., Graziotto, J., Jeong, H., Simunovic, F., Klein, C., and Krainc, D. (2011). Mitochondrial Parkin recruitment is impaired in neurons derived from mutant PINK1 induced pluripotent stem cells. $J$. Neurosci. 31, 5970-5976.

Sethi, K. D. (2010). The impact of levodopa on quality of life in patients with Parkinson disease. Neurologist $16,76-83$.

Soldner, F., Hockemeyer, D., Beard, C., Gao, Q., Bell, G. W., Cook, E. G., Hargus, G., Blak, A., Cooper, O., Mitalipova, M., Isacson, O., and Jaenisch, R. (2009). Parkinson's disease patient-derived induced pluripotent stem cells free of viral reprogramming factors. Cell 136, 964-977.

Song, J., Lee, S. T., Kang, W., Park, J. E., Chu, K., Lee, S. E., Hwang, T., Chung, H., and Kim, M. (2007). Human embryonic stem cell-derived neural precursor transplants attenuate apomorphine-induced rotational behavior in rats with unilateral quinolinic acid lesions. Neurosci. Lett. 423, 58-61.

Suter, D. M., and Krause, K. H. (2008). Neural commitment of embryonic stem cells: molecules, pathways and potential for cell therapy. J. Pathol. 215, 355-368.

Suter, D. M., Preynat-Seauve, O., Tirefort, D., Feki, A., and Krause, K. H. (2009). Phenazopyridine induces and synchronizes neuronal differentiation of embryonic stem cells. $J$. Cell. Mol. Med. 13, 3517-3527.

Swistowski, A., Peng, J., Han, Y., Swistowska, A. M., Rao, M. S., and Zeng, X. (2009). Xeno-free defined conditions for culture of human embryonic stem cells, neural stem cells and dopaminergic neurons derived from them. PLoS ONE 4, e6233. doi:10.1371/journal.pone.0006233

Swistowski, A., Peng, J., Liu, Q., Mali, P., Rao, M. S., Cheng, L., and Zeng, X. (2010). Efficient generation of functional dopaminergic neurons from human induced pluripotent stem cells under defined conditions. Stem Cells 28, 1893-1904.

Takahashi, K., Tanabe, K., Ohnuki, M. Narita, M., Ichisaka, T., Tomoda, K. and Yamanaka, S. (2007). Induction of pluripotent stem cells from adult human fibroblasts by defined factors. Cell 131, 861-872.

Tan, H. L., Fong, W. J., Lee, E. H., Yap, M., and Choo, A. (2009). mAb 84, a cytotoxic antibody that kills undifferentiated human embryonic stem cells via oncosis. Stem Cells 27 , 1792-1801.

Thomson, J. A., Itskovitz-Eldor, J., Shapiro, S. S., Waknitz, M. A. Swiergiel, J. J., Marshall, V. S., and Jones, J. M. (1998). Embryonic stem cell lines derived from human blastocysts. Science 282, 1145-1147.

Tian, C., Wang, Y., Sun, L., Ma, K., and Zheng, J. C. (2011). Reprogrammed mouse astrocytes retain a "memory" of tissue origin and possess more tendencies for neuronal differentiation than reprogrammed mouse embryonic fibroblasts. Protein Cell 2 , 128-140.

Tuszynski, M. H. (2007). Nerve growth factor gene therapy in Alzheimer disease. Alzheimer Dis. Assoc. Disord. 21 , 179-189.

Vierbuchen, T., Ostermeier, A., Pang, Z P., Kokubu, Y., Sudhof, T. C., and Wernig, M. (2010). Direct conversion of fibroblasts to functional neurons by defined factors. Nature 463 , 1035-1041.

Wang, A., Tang, Z., Park, I. H., Zhu, Y., Patel, S., Daley, G. Q., and Li, S. (2011). Induced pluripotent stem cells for neural tissue engineering. Biomaterials 32, 5023-5032.

Wang, Q., Matsumoto, Y., Shindo, T., Miyake, K., Shindo, A., Kawanishi, M., Kawai, N., Tamiya, T., and Nagao, S. (2006). Neural stem cells transplantation in cortex in a mouse model of Alzheimer's disease. J. Med. Invest. 53, 61-69.

Warren, G., and Yellowlees, P. (1990). The prevalence of Huntington's disease. Med. J. Aust. 153, 629.
Wilby, M. J., Muir, E. M., Fok-Seang, J., Gour, B. J., Blaschuk, O. W., and Fawcett, J. W. (1999). N-Cadherin inhibits Schwann cell migration on astrocytes. Mol. Cell. Neurosci. 14, 66-84.

Yamanaka, S. (2008). Induction of pluripotent stem cells from mouse fibroblasts by four transcription factors. Cell Prolif. 41 (Suppl. 1), 51-56.

Yazawa, M., Hsueh, B., Jia, X., Pasca, A. M., Bernstein, J. A., Hallmayer, J., and Dolmetsch, R. E. (2011). Using induced pluripotent stem cells to investigate cardiac phenotypes in Timothy syndrome. Nature 471, 230-234.

Yoshida, Y., Takahashi, K., Okita, K., Ichisaka, T., and Yamanaka, S. (2009). Hypoxia enhances the generation of induced pluripotent stem cells. Cell Stem Cell 5, 237-241.

Yu, J., Vodyanik, M. A., Smuga-Otto, K., Antosiewicz-Bourget, J., Frane, J. L., Tian, S., Nie, J., Jonsdottir, G. A., Ruotti, V., Stewart, R., Slukvin, Ii, and Thomson, J. A. (2007). Induced pluripotent stem cell lines derived from human somatic cells. Science 318, 1917-1920.

Zhou, H., Wu, S., Joo, J. Y., Zhu, S., Han, D. W., Lin, T., Trauger, S., Bien, G., Yao, S., Zhu, Y., Siuzdak, G., Scholer, H. R., Duan, L., and Ding, S. (2009). Generation of induced pluripotent stem cells using recombinant proteins. Cell Stem Cell 4, 381-384.

Conflict of Interest Statement: The authors declare that the research was conducted in the absence of any commercial or financial relationships that could be construed as a potential conflict of interest.

Received: 15 December 2011; paper pending published: 01 January 2012; accepted: 21 February 2012; published online: 19 March 2012.

Citation: Martinez Y, Dubois-Dauphin $M$ and Krause K-H (2012) Generation and applications of human pluripotent stem cells induced into neural lineages and neural tissues. Front. Physio. 3:47. doi: 10.3389/fphys.2012.00047

This article was submitted to Frontiers in Craniofacial Biology, a specialty of Frontiers in Physiology.

Copyright (c) 2012 Martinez, DuboisDauphin and Krause. This is an openaccess article distributed under the term of the Creative Commons Attribution Non Commercial License, which permits non-commercial use, distribution, and reproduction in other forums, provided the original authors and source are credited. 